University of Nebraska - Lincoln

DigitalCommons@University of Nebraska - Lincoln

Faculty Papers and Publications in Animal

Science

Animal Science Department

March 2004

\title{
Responses to 19 generations of litter size selection in the Nebraska Index line. I. Reproductive responses estimated in pure line and crossbred litters
}

D. B. Petry

University of Nebraska-Lincoln

Rodger K. Johnson

University of Nebraska-Lincoln, rjohnson5@unl.edu

Follow this and additional works at: https://digitalcommons.unl.edu/animalscifacpub

Part of the Animal Sciences Commons

Petry, D. B. and Johnson, Rodger K., "Responses to 19 generations of litter size selection in the Nebraska Index line. I. Reproductive responses estimated in pure line and crossbred litters" (2004). Faculty Papers and Publications in Animal Science. 116.

https://digitalcommons.unl.edu/animalscifacpub/116

This Article is brought to you for free and open access by the Animal Science Department at DigitalCommons@University of Nebraska - Lincoln. It has been accepted for inclusion in Faculty Papers and Publications in Animal Science by an authorized administrator of DigitalCommons@University of Nebraska - Lincoln. 


\title{
Responses to 19 generations of litter size selection in the Nebraska Index line. I. Reproductive responses estimated in pure line and crossbred litters ${ }^{1}$
}

\author{
D. B. Petry and R. K. Johnson ${ }^{2}$ \\ Department of Animal Science, University of Nebraska, Lincoln 68583-0908
}

\begin{abstract}
Our objective was to estimate responses in reproductive traits in the Nebraska Index line (I) after 19 generations of selection for increased litter size. Responses were estimated in dams producing pure line, $\mathrm{F}_{1}$, and three-way cross litters. A total of 850 litters were produced over six year-seasons, including 224 pure line litters, $393 \mathrm{~F}_{1}$ litters produced from $\mathrm{I}$ and $\mathrm{C}$ females mated with Danbred NA Landrace (L) or DurocHampshire $(\mathrm{T})$ boars, and 233 litters by $\mathrm{F}_{1} \mathrm{~L} \times \mathrm{I}$ and $\mathrm{L}$ $\times \mathrm{C}$ females mated with $\mathrm{T}$ boars. Contrasts of means were used to estimate the genetic difference between I and $\mathrm{C}$ and interactions of line differences with mating type. Farrowing rates of lines I ( $\hat{\mathrm{u}}=91.0 \%)$ and $\mathrm{C}(\hat{\mathrm{u}}=$ 92.8\%) did not differ. Averaged across all genetic groups, mean number born alive per litter was 10.1 pigs, and number and weight of pigs weaned per litter, both adjusted for number nursed and weaning age of
\end{abstract}

$12 \mathrm{~d}$, were 9.7 pigs and $34.4 \mathrm{~kg}$, respectively. Averaged across mating types, direct genetic effects of I were greater than $\mathrm{C}(P<0.05)$ for total born $(3.53$ pigs $)$, number born alive (2.53 pigs), number of mummified pigs $(0.22 \mathrm{pig})$, and litter birth weight $(2.14 \mathrm{~kg})$. The direct genetic effect of line I was less than $\mathrm{C}(P<0.05)$ for litter weaning weight $(-1.88 \mathrm{~kg})$. Interactions of line effects with crossing system were significant $(P<0.05)$ for total number born, number of stillborn pigs, number weaned, and litter weaning weight. In pure line litters, I exceeded $\mathrm{C}$ by 4.18 total pigs and 1.76 stillborn pigs per litter, whereas the estimate of $\mathrm{I}-\mathrm{C}$ in $\mathrm{F}_{1}$ litters was 2.74 total pigs and 0.78 stillborn pig per litter. The contrast between I and $\mathrm{C}$ for number weaned and litter weaning weight in pure litters was 0.32 pig and -0.28 $\mathrm{kg}$, respectively, compared with 0.25 pig and $-2.14 \mathrm{~kg}$ in $F_{1}$ litters. Crossbreeding is an effective way to use the enhanced reproductive efficiency of the Index line.

Key Words: Crossbreeding, Litter Size, Reproduction, Selection

(2004 American Society of Animal Science. All rights reserved.

J. Anim. Sci. 2004. 82:1000-1006

\section{Introduction}

Reducing age at conception, weaning-to-conception interval, lactation length, weaning-to-culling period and/or increasing conception rate, litter size, and preweaning survival rate will increase pigs produced per sow per year and efficiency of producing lean pork (Tess et al., 1983; Irgang and Robison, 1984). Between 30 to $40 \%$ of the ova released during the estrous cycle in which females are mated are not represented by a live pig at birth (Pope and First, 1985). Therefore, procedures to increase litter size through increased ovulation rate and decreased fetal losses during gestation offer the greatest opportunity to increase reproductive efficiency.

\footnotetext{
${ }^{1}$ Published as paper No. 13928, Journal Ser., Nebraska Agric. Res. Div., Univ. of Nebraska, Lincoln 68583-0908.

${ }^{2}$ Correspondence: A218 Animal Sciences (phone: 402-472-6404; fax: 402-472-6362; e-mail: rjohnson5@unl.edu).

Received May 12, 2003.

Accepted January 5, 2004.
}

In the past, it was commonly believed that selection for increased litter size would be relatively ineffective (Haley et al., 1988) unless very high selection intensities in large populations were used (Legault and Gruand, 1976). But in more recent experiments, selection for increased litter size was effective (Lamberson et al., 1991; Johnson et al., 1999). Litter size is a relatively complex trait, determined by ovulation rate and the proportion of ova resulting in offspring at term or, alternatively, by the number of potentially viable embryos and the capacity of the uterus (Bennett and Leymaster, 1989). Johnson et al. (1999) reported results of 10 generations of index selection for ovulation rate and embryonic survival followed by three generations of direct litter size selection. Selection for increased litter size was continued in the Nebraska Index line and a crossing experiment utilizing females from Generations 17, 18 , and 19 was conducted. The objectives of the research reported herein were to 1 ) estimate direct and correlated responses in litter size and its components and in number and weight of pigs weaned and 2) estimate responses in crossbred applications. 
Table 1. Number of litters of each group produced per year/season

\begin{tabular}{|c|c|c|c|c|c|c|c|c|}
\hline \multicolumn{3}{|c|}{ Genetic group $^{\mathrm{a}}$} & \multicolumn{6}{|c|}{ Year/season ${ }^{b}$} \\
\hline Sire & Dam & Litter & $1998 / 1$ & $1998 / 2$ & $1999 / 1$ & $1999 / 2$ & $2000 / 1$ & $2000 / 2$ \\
\hline $\mathrm{C}$ & C & $\mathrm{C}$ & 36 & & 39 & & 35 & \\
\hline I & $\mathrm{I}$ & I & 44 & & 35 & & 35 & \\
\hline $\mathrm{L}$ & $\mathrm{C}$ & $\mathrm{L} \times \mathrm{C}$ & 45 & & 35 & & 25 & 24 \\
\hline $\mathrm{L}$ & $\mathrm{I}$ & $\mathrm{L} \times \mathrm{I}$ & 49 & & 27 & & 25 & 20 \\
\hline $\mathrm{T}$ & $\mathrm{C}$ & $\mathrm{T} \times \mathrm{C}$ & & 47 & & 32 & & \\
\hline $\mathrm{T}$ & I & $\mathrm{T} \times \mathrm{I}$ & & 43 & & 20 & & \\
\hline $\mathrm{T}$ & $\mathrm{L} \times \mathrm{C}$ & $\mathrm{T}(\mathrm{L} \times \mathrm{C})$ & & & 43 & 16 & 37 & 22 \\
\hline $\mathrm{T}$ & $\mathrm{L} \times \mathrm{I}$ & $\mathrm{T}(\mathrm{L} \times \mathrm{I})$ & & & 43 & 17 & 33 & 20 \\
\hline
\end{tabular}

\section{Materials and Methods}

Population. The population was a composite of Large White and Landrace produced by reciprocally crossing boars and sows of the two breeds in 1979. Random selection and mating of the $\mathrm{F}_{1}$ and $\mathrm{F}_{2}$ generations were used to produce $\mathrm{F}_{3}$ litters. Pigs within these litters, born in 1981 and designated Generation 0, were randomly assigned to the Control line (C) that was randomly selected or the Index line (I) that was selected for an index of ovulation rate and embryonic survival. Details of the selection experiment and responses through Generation 14 are in Johnson et al. (1999). After 10 generations of index selection, I exceeded C by 7.4 ova and 3.8 fetuses at $50 \mathrm{~d}$ of gestation, and by 2.3 fully formed pigs and 1.1 live pigs at birth. Recording of ovulation sites and number of fetuses terminated at Generation 11, and selection during Generations 12 through 14 in I was on number of fully formed pigs per litter at birth. Responses at Generation 14 were 3.0 fully formed pigs and 1.4 live pigs per litter. During Generations 15 and 16 , I was first selected for number born alive and then within-litter selection for birth weight was practiced. The experiment reported herein was conducted with pigs from Generations 17 through 19.

Mating Design. Litters of eight genetic groups were produced in summer and winter farrowing seasons during 1998, 1999, and 2000, which corresponded with Generations 17 through 19 of the selection lines (Table 1). Genetic groups included pure line I and $\mathrm{C}$ pigs and crosses of I and C females with Landrace $(\mathbf{L})$ and $3 / 4$ Duroc $\times 1 / 4$ Hampshire terminal sires $(\mathbf{T})$. Crossbred litters were produced by artificial insemination with semen of $\mathrm{L}$ and $\mathrm{T}$ boars supplied by Danbred NA (Seward, NE). Vials of L and T semen were obtained from pools of semen collected from two to four boars per line. Semen of the same pool was used across both lines of sows.

Generation-16 I and $\mathrm{C}$ gilts were randomly assigned to be mated naturally to boars of the same line or to be inseminated with semen of $\mathrm{L}$ to produce Generation$17 \mathrm{I} \times \mathrm{I}, \mathrm{L} \times \mathrm{I}, \mathrm{C} \times \mathrm{C}$, and $\mathrm{L} \times \mathrm{C}$ litters. A random sample of $\mathrm{I}$ and $\mathrm{C}$ sows was retained after weaning their litters and inseminated with semen of $\mathrm{T}$ to produce $\mathrm{T} \times \mathrm{I}$ and $\mathrm{T} \times \mathrm{C}$ litters at their second parity. Sows were culled after weaning their second litter.

Breeding commenced during the same week each year for each season so that gilts farrowed at an average age of approximately $365 \mathrm{~d}$ of age and second-parity litters by sows were produced approximately 5 mo later. The breeding period for summer farrowing seasons, which included only gilts, was approximately $6 \mathrm{wk}$ long. A 3-wk breeding period was used for winter litters, which included only second-parity sows. During the breeding period, sows and gilts were checked each morning for signs of estrus and either mated naturally or were artificially inseminated that afternoon and again the next morning. Gilts were mated again if they returned to estrus during the breeding period.

Pure line and $\mathrm{F}_{1}$ gilts from the Generation-17 litters were retained for breeding to produce Generation-18 progeny. Pure line gilts were again randomly assigned to be mated naturally to boars of their own line or to be inseminated with semen of L boars. Crossbred gilts were inseminated with semen from $\mathrm{T}$ boars. Genetic types produced in Generation 18 were $\mathrm{I} \times \mathrm{I}, \mathrm{L} \times \mathrm{I}, \mathrm{C} \times$ $\mathrm{C}, \mathrm{L} \times \mathrm{C}, \mathrm{T}(\mathrm{L} \times \mathrm{I})$, and $\mathrm{T}(\mathrm{L} \times \mathrm{C})$. A random sample of both pure line and $\mathrm{F}_{1}$ sows was retained after weaning their litters and inseminated with semen of $\mathrm{T}$ boars to produce $\mathrm{T} \times \mathrm{I}, \mathrm{T} \times \mathrm{C}, \mathrm{T}(\mathrm{L} \times \mathrm{I})$, and $\mathrm{T}(\mathrm{L} \times \mathrm{C})$ litters. No pigs in these litters were retained for breeding and all sows were culled after weaning their litters.

Pure line and $\mathrm{F}_{1}$ gilts from Generation 18 were retained and mated according to the same design as the one used to produce Generation-18 litters. After weaning these litters, a random sample of sows was retained for a second litter. Pure line I and C sows were inseminated with semen of $L$ boars, and $F_{1}$ sows were inseminated with semen of $\mathrm{T}$ boars.

Selection. Because birth weights and postnatal survival rate had decreased within Line I during the first 14 generations of selection, beginning with Generation 15, selection in Line I was for increased litter size and increased birth weight. This selection continued during Generations 17 through 19. Litters were first ranked for number born alive and then two boars with the 
heaviest birth weights were selected from each of the top 15 litters. Gilts were selected similarly; however, because more gilts were needed, they were selected from the top $50 \%$ of the litters for number born alive. Within these litters, gilts with low birth weight were culled and a maximum of four gilts per litter were selected. In Line C, one breeding boar was selected randomly within each paternal half-sib family and one or two gilts were selected randomly per litter to give 15 breeding boars and the necessary number of gilts each generation.

Data Collection. A total of 850 litters over six seasons, consisting of 224 purebred, $393 \mathrm{~F}_{1}$, and 233 three-way crosses, were studied. Farrowing rate (FR) was calculated as the percentage of gilts designated for breeding that farrowed a litter. All females were pregnancychecked at $50 \mathrm{~d}$ after breeding with an Ilis preg-test 737 (International Livestock Improvement Services Corp., Ames, IA) and those classified as nonpregnant were culled. Number of fully formed pigs (FF), number born alive (BA), numbers of stillborn (SB) and mummified piglets (MUM), and litter birth weight (LBW) were recorded at birth of litters.

Pigs were transferred among litters within $1 \mathrm{~d}$ of birth to partially standardize number of pigs nursed by dams. It was not possible to uniformly standardize all litters or to transfer pigs only within line. The goal was to reduce large litters to 12 pigs or fewer and not necessarily to increase the number in small litters. Therefore, pigs were transferred randomly among available litters without regard for the genetic makeup of dam or pig. Pig identification was maintained and the number and pedigree of pigs nursing each dam were recorded. The percentages of females nursing 12 pigs or fewer were $97.4,79.9,95.6$, and $83.1 \%$ for C, I, L $\times$ $\mathrm{C}$, and $\mathrm{L} \times \mathrm{I}$ sows, respectively. The mean number of pigs nursed by sows ranged from 10.4 for $\mathrm{C} \times \mathrm{L}$ gilts to 11.3 for I sows producing $\mathrm{T} \times \mathrm{I}$ litters. Pigs were weaned between 12 and $14 \mathrm{~d}$ and number weaned (NW) and weight of each pig were recorded at weaning. These variables were adjusted for number of pigs in the litter after transfer as described below to account for the variation among groups that remained after transferring pigs among litters.

Statistical Analyses. Farrowing rate was analyzed using a logistic model assuming a binomial distribution with the GLIMMIX macro of SAS (SAS Inst. Inc., Cary, $\mathrm{NC})$. The proportion of the number of females that farrowed to the number designated for breeding within each line of litter by year/season by mating type subclass was fitted to a model including the fixed effects of line of litter within season and the type of service (natural or AI). Linear predictors of farrowing rate were computed on the logit scale and contrasts to make specific comparisons of interest were made. Probabilities were calculated by applying the inverse link function $\pi=\exp (\mathrm{X} \beta) /[1+\exp (\mathrm{X} \beta)]$, where $\pi$ is the vector of predicted probabilities for each genetic group by season, $\mathrm{X}$ is the coefficient matrix, and $\boldsymbol{\beta}$ is the solution vector.
Traits recorded at birth were analyzed with PROC GLM. The model included the fixed effect of line within year/season subclass. Because all genetic groups were not produced in each year/season, linear contrasts of least squares means (Table 2) were applied within year/ season to estimate responses to selection in Line I, interactions of selection responses when expressed in pure line or crossbred applications, and responses due to crossbreeding. First, the overall difference in direct effect between I and $\mathrm{C}$ was estimated. Then, three interaction contrasts were calculated to determine whether the response differed: 1 ) in pure line dams producing pure line litters and pure line dams producing $\mathrm{F}_{1}$ litters, 2 ) in pure line dams producing $F_{1}$ Landrace cross litters or $\mathrm{F}_{1}$ terminal-cross litters, and 3) $\mathrm{F}_{1}$ dams producing three-way-cross litters and pure line dams producing $\mathrm{F}_{1}$ litters. If interactions existed $(P<0.05)$, responses in each of the three applications were estimated. Finally, the average of $\mathrm{I}$ and $\mathrm{C}$ pure line dams with $\mathrm{F}_{1}$ litters and I and $C$ dams with pure line litters, and the average of $\mathrm{F}_{1}$ dams with three-way-cross litters and pure line dams with $F_{1}$ litters were estimated. Coefficients that estimated $100 \%$ of the direct genetic difference between lines were used.

Litter weaning weight was recorded as the sum of weights at weaning of the pigs nursed by each dam. The objective was to compare dams of each genetic group for differences in maternal ability. To account for effects of genetic makeup of the pig, each pig was assigned the number weaned and the total weight of the litter and fitted to a mixed model that included fixed effects of genetic makeup of line of nurse dam and genetic makeup of the pig, both classified within year/season, and the random effect of the nurse dam. Age at weaning and the number of pigs after transfer among litters were fitted as covariates. Data were analyzed with Proc Mixed. Contrasts of least squares means (Table 3 ) were used to estimate genetic differences between I and C dams to test whether an interaction of selection response measured in pure line or crossbred dams existed, and to estimate the difference between $F_{1}$ and pure line dams. Results compare maternal ability of dams of each line as though they were nursing an equal number of pigs of the same genetic makeup and weaned at the same age.

\section{Results and Discussion}

Breeding Efficiency. The overall mean farrowing rate was $92.0 \%$ and averaged $91.0 \%$ for Line I dams compared with $92.8 \%$ for Line $\mathrm{C}$ dams $(P=0.64)$. No correlated response in fertility from selection for litter size occurred.

Farrowing rate for pure line I and $\mathrm{C}$ females artificially inseminated to $\mathrm{L}$ boars was $8.3 \%$ less than for those mated naturally to produce pure line litters $(P<$ 0.01 ). This reduction was not likely a genetic effect of line of service sire, but could have been caused by 
Table 2. Coefficients of contrasts among estimates of litter genetic type effects for traits measured at birth

\begin{tabular}{|c|c|c|c|c|c|c|c|c|c|c|}
\hline Year/season ${ }^{\mathrm{a}}$ & Group $^{b}$ & $\mathrm{I}-\mathrm{C}^{\mathrm{c}}$ & $\mathrm{R}: \mathrm{P}-\mathrm{F}_{1}{ }^{\mathrm{d}}$ & $\mathrm{R}: \mathrm{P}-\mathrm{T}^{\mathrm{e}}$ & $R: T-F_{1}{ }^{f}$ & $(\mathrm{I}-\mathrm{C})_{\mathrm{p}}^{\mathrm{g}}$ & $(\mathrm{I}-\mathrm{C})_{\mathrm{F} 1}{ }^{\mathrm{h}}$ & $(\mathrm{I}-\mathrm{C})_{\mathrm{F} 1}{ }^{\mathrm{i}}$ & $\mathrm{F}_{1}-\mathrm{P}^{\mathrm{j}}$ & $\mathrm{T}-\mathrm{F}_{1}{ }^{\mathrm{k}}$ \\
\hline \multirow[t]{4}{*}{$1998 / 1$} & $\mathrm{C} \times \mathrm{C}$ & -1 & -1 & & & -1 & & & -1 & \\
\hline & $\mathrm{I} \times \mathrm{I}$ & 1 & 1 & & & 1 & & & -1 & \\
\hline & $\mathrm{I} \times \mathrm{C}$ & -1 & 1 & & & & -1 & & 1 & \\
\hline & $\mathrm{L} \times \mathrm{I}$ & 1 & -1 & & & & 1 & & 1 & \\
\hline \multirow[t]{2}{*}{$1998 / 2$} & $\mathrm{~T} \times \mathrm{C}$ & -1 & & & & & -1 & & & \\
\hline & $\mathrm{T} \times \mathrm{I}$ & 1 & & & & & 1 & & & \\
\hline \multirow[t]{6}{*}{$1999 / 1$} & $\mathrm{C} \times \mathrm{C}$ & -1 & -1 & -1 & & -1 & & & -1 & \\
\hline & $\mathrm{I} \times \mathrm{I}$ & 1 & 1 & 1 & & 1 & & & -1 & \\
\hline & $\mathrm{L} \times \mathrm{C}$ & -1 & 1 & & -1 & & -1 & & 1 & -1 \\
\hline & $\mathrm{L} \times 1$ & 1 & -1 & & 1 & & 1 & & 1 & -1 \\
\hline & $\mathrm{T}(\mathrm{L} \times \mathrm{C})$ & -2 & & 2 & 2 & & & -2 & & 1 \\
\hline & $\mathrm{T}(\mathrm{L} \times \mathrm{I})$ & 2 & & -2 & -2 & & & 2 & & 1 \\
\hline \multirow[t]{4}{*}{$1999 / 2$} & $\mathrm{~T} \times \mathrm{C}$ & -1 & & & -1 & & -1 & & & -1 \\
\hline & $\mathrm{T} \times \mathrm{I}$ & 1 & & & 1 & & 1 & & & -1 \\
\hline & $\mathrm{T}(\mathrm{L} \times \mathrm{C})$ & -2 & & & 2 & & & -2 & & 1 \\
\hline & $\mathrm{T}(\mathrm{L} \times \mathrm{I})$ & 2 & & & -2 & & & 2 & & 1 \\
\hline \multirow[t]{6}{*}{$2000 / 1$} & $\mathrm{C} \times \mathrm{C}$ & -1 & -1 & -1 & & -1 & & & -1 & \\
\hline & $\mathrm{I} \times \mathrm{I}$ & 1 & 1 & 1 & & 1 & & & -1 & \\
\hline & $\mathrm{L} \times \mathrm{C}$ & -1 & 1 & & -1 & & -1 & & 1 & -1 \\
\hline & $\mathrm{L} \times \mathrm{I}$ & 1 & -1 & & 1 & & 1 & & 1 & -1 \\
\hline & $\mathrm{T}(\mathrm{L} \times \mathrm{C})$ & -2 & & 2 & 2 & & & -2 & & 1 \\
\hline & $\mathrm{T}(\mathrm{L} \times \mathrm{I})$ & 2 & & -2 & -2 & & & 2 & & 1 \\
\hline \multirow[t]{4}{*}{$2000 / 2$} & $\mathrm{~L} \times \mathrm{C}$ & -1 & & & -1 & & -1 & & & -1 \\
\hline & $\mathrm{L} \times \mathrm{I}$ & 1 & & & 1 & & 1 & & & -1 \\
\hline & $\mathrm{T}(\mathrm{L} \times \mathrm{C})$ & -2 & & & 2 & & & -2 & & 1 \\
\hline & $\mathrm{T}(\mathrm{L} \times \mathrm{I})$ & 2 & & & -2 & & & 2 & & 1 \\
\hline Divisor & & 13 & 3 & 2 & 4 & 3 & 6 & 4 & 6 & 8 \\
\hline
\end{tabular}

aseason 1 = summer, season 2 = winter.

${ }^{\mathrm{b}} \mathrm{C}=$ control, $\mathrm{I}=$ index, $\mathrm{L}=$ Danbred NA Landrace sire, $\mathrm{T}$ = Danbred NA Duroc-Hampshire terminal sire. ${ }^{\mathrm{C}} \mathrm{I}-\mathrm{C}=$ average overall difference in direct effect between Lines I and $\mathrm{C}$.

${ }^{d} \mathrm{R}: \mathrm{P}-\mathrm{F} 1$ tests the interaction of selection response (I-C) in pure line dams with pure line litters vs. pure line dams with $\mathrm{F}_{1}$ litters.

${ }^{e} \mathrm{R}: \mathrm{P}-\mathrm{T}$ tests the interaction of selection response (I-C) in pure line dams with pure line litters vs. $\mathrm{F}_{1}$ dams with three-way cross litters.

${ }^{\mathrm{f}} \mathrm{R}: \mathrm{F} 1-\mathrm{T}$ tests the interaction of selection response (I-C) in pure line dams with $\mathrm{F}_{1}$ litters vs. $\mathrm{F}_{1}$ dams with three-way cross litters.

${ }^{\mathrm{g}}(\mathrm{I}-\mathrm{C})_{\mathrm{p}}=$ difference in direct effects between $\mathrm{I}$ and $\mathrm{C}$ when measured in pure line dams producing pure line litters.

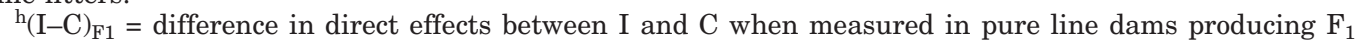
litters.

${ }^{\mathrm{i}}(\mathrm{I}-\mathrm{C})_{\mathrm{T}}=$ difference in direct effects between $\mathrm{I}$ and $\mathrm{C}$ when measured in $\mathrm{F}_{1}$ dams producing terminal, three-way-cross litters.

${ }^{j} \mathrm{~F}_{1}-\mathrm{P}=$ average difference between $\mathrm{I}$ and $\mathrm{C}$ pure line dams producing $\mathrm{F}_{1}$ litters and pure line dams producing pure line litters.

${ }^{\mathrm{k}} \mathrm{T}-\mathrm{F}_{1}=$ average difference between $\mathrm{F}_{1}$ dams producing three-way cross litters and pure line dams producing $\mathrm{F}_{1}$ litters.

improper AI techniques or by better timing of insemination with ovulation when natural mating occurred.

Johnson (1980) reported that conception rates did not differ among crossbred females or among purebred females, but average conception rate was greater for crossbreds. Results of our experiment were similar, as conception rate for $F_{1}$ females producing three-waycross litters was $8.6 \%$ greater than for pure line females artificially inseminated to produce $\mathrm{F}_{1}$ litters $(P<0.01)$.

Age at puberty was not recorded in this experiment. It was recorded in Generation-16 I and C gilts and averaged 176.1 and $175.7 \mathrm{~d}$, respectively. Age at puberty of the population of Landrace used herein is not known, but Hutchens et al. (1982) studied a population of Landrace with mean age at puberty of $194.5 \mathrm{~d}$. They also found heterosis for age at puberty to be $-8.8 \mathrm{~d}$. Gilts were mated at an average age of approximately $240 \mathrm{~d}$ to farrow at $1 \mathrm{yr}$ of age and most would likely have been mated at second or third postpubertal estrus. Therefore, bias in differences between lines in conception rate, or in the traits discussed below, due to differences in age at puberty is not expected.

Birth Traits. Table 4 contains contrasts among means for traits measured at birth. Estimates of changes in direct genetic effects of dams to selection for increased litter size were $3.53 \pm 0.30$ fully formed pigs, $2.53 \pm$ 0.30 live pigs, $0.99 \pm 0.18$ stillborn pig, $0.22 \pm 0.06$ mummified piglet, and $2.14 \pm 0.35 \mathrm{~kg}$ litter birth weight. In comparison, responses after 14 generations of selection were estimated to be 2.97 fully formed pigs, 1.44 
Table 3. Coefficients of contrasts among line of dam estimates of litter genetic type effects for number and weight of pigs at weaning

\begin{tabular}{|c|c|c|c|c|c|c|}
\hline Year/season ${ }^{\mathrm{a}}$ & Line of dam ${ }^{b}$ & $\mathrm{I}-\mathrm{C}^{\mathrm{c}}$ & $\mathrm{R}: \mathrm{F}_{1}-\mathrm{P}^{\mathrm{d}}$ & $(\mathrm{I}-\mathrm{C})_{\mathrm{P}}^{\mathrm{e}}$ & $(\mathrm{I}-\mathrm{C})_{\mathrm{F} 1}{ }^{\mathrm{f}}$ & $\mathrm{F}_{1}-\mathrm{P}^{\mathrm{g}}$ \\
\hline \multirow[t]{2}{*}{$1998 / 1$} & $\mathrm{C}$ & -1 & & -1 & & \\
\hline & $\mathrm{I}$ & 1 & & 1 & & \\
\hline \multirow[t]{2}{*}{$1998 / 2$} & $\mathrm{C}$ & -1 & & -1 & & \\
\hline & $\mathrm{I}$ & 1 & & 1 & & \\
\hline \multirow[t]{4}{*}{$1999 / 1$} & $\mathrm{C}$ & -1 & 1 & -1 & & -1 \\
\hline & I & 1 & -1 & 1 & & -1 \\
\hline & $\mathrm{L} \times \mathrm{C}$ & -2 & -2 & & -2 & 1 \\
\hline & $\mathrm{L} \times \mathrm{I}$ & 2 & 2 & & 2 & 1 \\
\hline \multirow[t]{4}{*}{$1999 / 2$} & $\mathrm{C}$ & -1 & 1 & -1 & & -1 \\
\hline & I & 1 & -1 & 1 & & -1 \\
\hline & $\mathrm{L} \times \mathrm{C}$ & -2 & -2 & & -2 & 1 \\
\hline & $\mathrm{L} \times \mathrm{I}$ & 2 & 2 & & 2 & 1 \\
\hline \multirow[t]{4}{*}{$2000 / 1$} & $\mathrm{C}$ & -1 & 1 & -1 & & -1 \\
\hline & I & 1 & -1 & 1 & & -1 \\
\hline & $\mathrm{L} \times \mathrm{C}$ & -2 & -2 & & -2 & 1 \\
\hline & $\mathrm{L} \times \mathrm{I}$ & 2 & 2 & & 2 & 1 \\
\hline \multirow[t]{4}{*}{$2000 / 2$} & $\mathrm{C}$ & -1 & 1 & -1 & & -1 \\
\hline & I & 1 & -1 & 1 & & -1 \\
\hline & $\mathrm{L} \times \mathrm{C}$ & -2 & -2 & & -2 & 1 \\
\hline & $\mathrm{L} \times \mathrm{I}$ & 2 & 2 & & 2 & 1 \\
\hline Divisor & & 10 & 4 & 6 & 4 & 4 \\
\hline
\end{tabular}

live pigs, 1.61 stillborn pigs, and 0.41 mummified pig per litter, and $0.81 \mathrm{~kg}$ in litter birth weight (Johnson et al., 1999).

Interaction of the estimated genetic difference between I and $\mathrm{C}$ dams with type of litter they produced existed $(P<0.05)$. The genetic difference between I and $\mathrm{C}$ dams in pure line dams producing pure line litters was $4.18 \pm 0.39$ pigs, whereas the difference in pure line dams producing $\mathrm{F}_{1}$ litters was $2.75 \pm 0.30$ pigs. Increased birth weight in $\mathrm{F}_{1}$ litters may partially explain this interaction. Uterine capacity, the number of fetuses the uterus can carry to term when number of fertilized ova is not limiting (Bennett and Leymaster, 1989), is a main limiting component of litter size at birth. If uterine capacity limits both number of pigs and mass of pigs carried to term, then pure line pigs with $\mathrm{F}_{1}$ litters would produce that same mass with fewer pigs than pure line dams with pure line pigs. Another possible explanation is that better timing of insemination with ovulation occurred with natural mating and that fewer ova were fertilized when $\mathrm{F}_{1}$ litters were produced with artificial insemination.

Number of fully formed pigs in litters by $\mathrm{I}$ and $\mathrm{C}$ dams with $\mathrm{F}_{1}$ litters was less $(-0.83 \pm 0.28, P<0.01)$ than when they produced pure line litters. This was not expected as heterosis for fetal survival rate is positive and usually results in larger $\mathrm{F}_{1}$ litters than purebred litters (Johnson, 1980). Although not significant, there were also fewer stillborn pigs in $\mathrm{F}_{1}$ litters. As a result, the difference in number of live pigs per litter was not significant, although there were more live pigs in pure line litters. This result is also consistent with the hypothesis that uterine capacity limits total weight of pigs carried to term. There were fewer pigs in $\mathrm{F}_{1}$ litters, but the pigs were heavier, and the difference in litter birth weight between pure line dams with pure line and $\mathrm{F}_{1}$ litters was small and not significant. Threeway cross litters by $F_{1}$ dams were larger $(1.71 \pm 0.29$ more fully formed pigs per litter and $1.51 \pm 0.29$ more live pigs) and heavier $(3.47 \pm 0.33 \mathrm{~kg})$ at birth than the average of $\mathrm{I}$ and $\mathrm{C}$ dams with $\mathrm{F}_{1}$ litters. Differences in number of stillborn and mummified piglets were not significant.

Differences in ovulation rate and litter size between Danbred Landrace and Lines I and C are not known. However, little heterosis is expected for ovulation rate (Johnson, 1980) and maternal heterosis has been reported to increase number born by 0.5 to 1.0 pig per litter and litter birth weight by 0.5 to1.1 kg (Johnson, 1980; Bennett et al., 1983; Kuhlers et al., 1989). Because of the intense selection for litter size practiced in Line I, litter size of Danbred Landrace is not expected to exceed the average of I and $\mathrm{C}$ females. Although the increases in litter size and weight at birth of three-waycross litters over $\mathrm{F}_{1}$ litters was due to the net effects of maternal heterosis for uterine capacity and the substitution in dams of 50\% Danbred Landrace genes for I 
Table 4. Contrasts among means for traits recorded at birth ${ }^{\mathrm{a}}$

\begin{tabular}{|c|c|c|c|c|c|c|c|c|c|c|}
\hline \multirow[b]{2}{*}{ Contrast $^{\mathrm{b}}$} & \multicolumn{2}{|c|}{$\mathrm{FF}$} & \multicolumn{2}{|c|}{ NBA } & \multicolumn{2}{|c|}{ SB } & \multicolumn{2}{|c|}{ MUM } & \multicolumn{2}{|c|}{ LBW, kg } \\
\hline & $\hat{\mathrm{u}}$ & $\mathrm{SE}$ & $\hat{\mathrm{u}}$ & $\mathrm{SE}$ & $\hat{\mathrm{u}}$ & $\mathrm{SE}$ & $\hat{\mathrm{u}}$ & $\mathrm{SE}$ & $\hat{\mathrm{u}}$ & $\mathrm{SE}$ \\
\hline $\mathrm{I}-\mathrm{C}$ & $3.53^{* *}$ & 0.30 & $2.53^{* *}$ & 0.30 & $0.99 * *$ & 0.18 & $0.22 * *$ & 0.06 & $2.14^{* *}$ & 0.35 \\
\hline $\mathrm{R}: \mathrm{P}-\mathrm{F}_{1}$ & $-1.21^{*}$ & 0.57 & NS & & $-0.75^{* *}$ & 0.33 & NS & & NS & \\
\hline $\mathrm{R}: \mathrm{P}-\mathrm{T}$ & NS & & NS & & NS & & NS & & NS & \\
\hline $\mathrm{R}: \mathrm{T}-\mathrm{F}_{1}$ & NS & & NS & & NS & & NS & & NS & \\
\hline$(\mathrm{I}-\mathrm{C})_{\mathrm{P}}$ & $4.18^{* *}$ & 0.39 & & & $1.76^{* *}$ & 0.22 & & & & \\
\hline $\begin{array}{l}(\mathrm{I}-\mathrm{C})_{\mathrm{F} 1} \\
(\mathrm{I}-\mathrm{C})_{\mathrm{T}}\end{array}$ & $2.75^{* *}$ & 0.30 & & & $0.78^{* *}$ & 0.18 & & & & \\
\hline $\mathrm{F}_{1}-\mathrm{P}$ & $0.83^{* *}$ & 0.28 & -0.52 & 0.28 & -0.30 & 0.16 & -0.05 & 0.06 & 0.49 & 0.33 \\
\hline $\mathrm{T}-\mathrm{F}_{1}$ & $1.71^{* *}$ & 0.29 & $1.51^{* *}$ & 0.29 & 0.21 & 0.17 & -0.03 & 0.06 & $3.47 * *$ & 0.33 \\
\hline
\end{tabular}

${ }^{a} \mathrm{FF}=$ number of fully formed pigs; NBA = number of live pigs; $\mathrm{SB}=$ number of stillborn pigs; $\mathrm{MUM}=$ number of mummified pigs; LBW = litter birth weight.

${ }^{b}$ See Table 2 for definition of contrasts.

$* * P<0.01$

$* P<0.05$.

$\mathrm{NS}=$ not significant.

and $\mathrm{C}$ genes, most of the improvement is expected to be due to maternal heterosis.

Weaning Traits. Table 5 contains estimates of the contrasts among means for number of pigs and weight of litters at weaning. After adjusting for number of pigs, sows were given an opportunity to raise and for the genetic composition of the pigs they nursed, litters by Line I sows weighed $-1.88 \pm 0.73 \mathrm{~kg}$ less $(P<0.05)$ than those by Line $\mathrm{C}$ sows. Although not significant, number weaned by Line I sows was $-0.26 \pm 0.16$ pig less than for Line C sows. Mean pig weaning weight was 3.38 $\mathrm{kg}$. Therefore, the observed reduction in litter weaning weight was calculated to be due to smaller litters $(-0.26$ $\times 0.88=-0.88 \mathrm{~kg}$ ) and a correlated decrease in milk production and maternal ability $(-1.88-(-0.88)=-1.0$ $\mathrm{kg})$. Litter weaning weight measures both weight and number of pigs, whereas number weaned measures the survival rate of pigs. These results agree with those of Johnson et al. (1999), who reported reductions at Generation 14 in Line I gilts of -0.64 pig per litter and $-2.53 \mathrm{~kg}$ litter weaning weight and with the negative genetic correlations of -0.18 and -0.24 between litter weaning weight and ovulation rate in two other selec-

Table 5. Contrasts among means for traits recorded at weaning ${ }^{\mathrm{a}}$

\begin{tabular}{lccccc}
\hline \hline & \multicolumn{2}{c}{ LWW, kg } & & \multicolumn{2}{c}{$\mathrm{NW}$} \\
\cline { 2 - 3 } \cline { 5 - 6 } Contrast $^{\mathrm{b}}$ & $\hat{\mathrm{u}}$ & $\mathrm{SE}$ & & $\hat{\mathrm{u}}$ & $\mathrm{SE}$ \\
\hline $\mathrm{I}-\mathrm{C}$ & $-1.88^{*}$ & 0.73 & & -0.26 & 0.16 \\
$\mathrm{R}: \mathrm{P}-\mathrm{F}_{1}$ & $5.68^{* *}$ & 1.77 & & $1.80^{* *}$ & 0.39 \\
$(\mathrm{I}-\mathrm{C})_{\mathrm{P}}$ & -0.28 & 0.50 & & $0.32^{* *}$ & 0.11 \\
$(\mathrm{I}-\mathrm{C})_{\mathrm{F} 1}$ & $-2.14^{* *}$ & 0.82 & & $-0.56^{* *}$ & 0.18 \\
$\mathrm{~F}_{1}-\mathrm{P}$ & $5.55^{* *}$ & 0.54 & & $0.25^{* *}$ & 0.12 \\
\hline
\end{tabular}

${ }^{\mathrm{a}} \mathrm{LWW}=$ litter weaning weight; $\mathrm{NW}=$ number weaned.

${ }^{\mathrm{b}}$ See Table 3 for definition of contrasts.

$* * P<0.01$

$* P<0.05$.

$\mathrm{NS}=$ not significant. tion lines that were derived from Lines I and $\mathrm{C}$ at Generation 8 (Ruiz-Flores and Johnson, 2001).

There was an interaction in genetic response in number and weight of pigs at weaning with genetic type of dam $(P<0.01)$. The genetic difference in weaning weight between $\mathrm{I}$ and $\mathrm{C}$ when measured in $\mathrm{F}_{1}$ dams was $-2.14 \pm 0.82 \mathrm{~kg}(P<0.01)$; however, the difference in pure line dams was not significant $(-0.28 \pm 0.50$ $\mathrm{kg}$ ). The genetic difference in number weaned per litter between $\mathrm{I}$ and $\mathrm{C}$ dams differed in sign when measured in pure line and $\mathrm{F}_{1}$ dams. It was $-0.56 \pm 0.18$ pig $(P<$ $0.01)$ in $\mathrm{F}_{1}$ dams and $0.32 \pm 0.11$ pig $(P<0.01)$ in pure line dams. No supporting literature was found about whether selection responses in these traits are expressed differently in pure line and $F_{1}$ females.

Three-way-cross litters by $\mathrm{F}_{1}$ dams weighed $5.55 \pm$ $0.54 \mathrm{~kg}(P<0.01)$ more at weaning. Although significant, the difference in number weaned was small $(0.25$ \pm 0.12 pig) relative to the difference in litter weaning weight. Thus, $\mathrm{F}_{1}$ dams expressed significantly better mothering ability than pure line dams. This result is the net advantage due to maternal heterosis and the effect of substitution of 50\% Danbred Landrace genes for Line I and C genes. Johnson (1980) reported that crossbred dams weaned 0.58 pig more in litters that were $1.2 \mathrm{~kg}$ heavier than purebred dams. Bennett et al. (1983) reported that crossbred dams weaned 0.94 pig more in litters that were $5.6 \mathrm{~kg}$ heavier at weaning than pigs nursed by purebred dams. Thus, a significant part of the improved maternal ability of $\mathrm{F}_{1}$ dams was likely achieved through gene substitution effects of Danbred Landrace.

\section{Implications}

Ovulation rate, embryonic survival, and litter size are heritable and respond to selection, but selection only for these traits increases the incidence of stillborn and mummified pigs. Decreased postnatal milk produc- 
tion of dams and lighter weights of litters at weaning occurred in this study, but it is unclear whether these changes are responses correlated with selection or due to genetic drift. Realized responses may depend on how the improved line is used. In this study, increased litter size occurred in both pure line and $\mathrm{F}_{1}$ dams, but responses in $\mathrm{F}_{1}$ dams were less than in pure line dams. Crossbreeding is an effective strategy to use prolific lines, as the increased incidence of stillborn and mummified piglets in pure line litters is decreased with crossing. Crossing prolific lines will also improve maternal ability of sows and weights of litters at weaning. Crossing the Nebraska Index line with an unrelated maternal line effectively used the line's improved prolificacy.

\section{Literature Cited}

Bennett, G. L., and K. A. Leymaster. 1989. Integration of ovulation rate, potential embryonic viability and uterine capacity into a model of litter size in swine. J. Anim. Sci. 67:1230-1241.

Bennett, G. L., M. W. Tess, G. E. Dickerson, and R. K. Johnson. 1983. Simulation of breed and crossbreeding effects on costs of pork production. J. Anim. Sci. 56:801-813.

Haley, C. S., E. Avalos, and C. Smith. 1988. Selection for litter size in the pig. Animal Breed. Abstr., 56:317-332.
Hutchens, L. K., R. L. Hintz, and R. K. Johnson. 1982. Breed comparisons for age and weight at puberty in gilts. J. Anim. Sci. $55: 60-66$

Irgang, R., and O. W. Robison. 1984. Heritability estimates for ages at farrowing, rebreeding interval and litter traits in swine. J. Anim. Sci. 59:67-73.

Johnson, R. K. 1980. Heterosis and breed effects in swine. North Central Regional Pub. No. 262. Agric. Exp. Stn., Univ. Nebraska, Lincoln.

Johnson, R. K., M. K. Nielson, and D. S. Casey. 1999. Responses in ovulation rate, embryonic survival, and litter traits in swine to 14 generations of selection to increase litter size. J. Anim. Sci. 77:541-557.

Kuhlers, D. L., S. B. Jungst, and J. A. Little. 1989. Comparisons of specific crosses from Duroc-Landrace, Yorkshire-Landrace and Hampshire-Landrace sows managed in two types of gestation systems: Litter traits and sow weights. J. Anim. Sci. 67:920-927.

Lamberson, W. R., R. K. Johnson, D. R. Zimmerman, and T. E. Long. 1991. Direct response to selection for increased litter size, decreased age at puberty, or random selection following selection for ovulation rate in swine. J. Anim. Sci. 69:3129-3143.

Legault, C., and J. Gruand. 1976. Amélioration de la prolificité des truies par la création d'une lignée "hyperprolifique" et l'usage de l'insemination artificielle: principe et résultats experimentaux préliminaires. J. Rech. Porcine Fr. 8:201-206.

Pope, W. F., and N. L. First. 1985. Factors affecting the survival of pig embryos. Theriogenology 23:91-97.

Tess, M. W., G. L. Bennett, and G. E. Dickerson. 1983. Simulation of genetic changes in life cycle efficiency of pork production. II. Effects of components on efficiency. J. Anim. Sci. 56:354-368. 